\title{
Amitav Ghosh and the Art of Thick Description: History in the Ibis Trilogy
}

\author{
Mark R. Frost
}

University of Essex

Some years ago, I joined a workshop in Singapore at which historians of Asia engaged with writers who had produced critically-acclaimed works of historical fiction about the region. When pressed, the three authors present rejected the notion that they might themselves be considered 'historians'. Instead, they were keen to emphasise the borderline they felt divided what they did from what we did. However, it soon became apparent that the fiction-makers amongst us held an advantage which, in my own case, resulted in a distinct twinge of envy. Each author had enjoyed numerous opportunities to luxuriate in the archives. Each had amassed, and then evidently mastered, a stockpile of primary sources. Such sources had enabled these authors to tease out the mundane, the microscopic yet the often revelatory intricacies of the past. All this had been achieved minus the burden of them having to justify their endeavours to research councils and grant bodies. Since my long-gone, halcyon, graduate student days, my own relationship with primary research had become considerably more impatient. As an academic historian I hungered for that instant archival gratification that assuaged the pent-up frustrations born of teaching, marking and departmental administration. Compared to these writers who could afford time to linger in the world's great repositories, I had become the scholarly equivalent of a smash-and-grab raider, ransacking the shelves for a quick fix, ever fearful that the authorities might arrive at any moment to return me to my institution.

When the novelists at the workshop were further encouraged to share their views on academic history-writing they confessed their frustrations - with a discipline which too often 
obscured its achievements in appalling prose, and with a historiography that, for their purposes, contained so many gaps that it brought to mind Tolstoy's complaint that historians 'are like deaf people who go on answering questions that no one has asked them.' ${ }^{1}$ Amitav Ghosh was not one of the speakers present; at the time, he was probably deep in a draft of Sea of Poppies, the first part of his Ibis trilogy. Nevertheless, his thoughts on the relationship between historical fiction and academic historical research likewise resonate and deserve a similar airing.

Amitav Ghosh is another who has demurred on the question of his own status as a 'historian'. For him, historical facts provide merely the 'scaffolding' for the characters he creates, who remain his main motivation for writing. With a typical poeticism, he has described history as 'like a river': the historian writes about 'the ways the river flows and the currents and crosscurrents', whereas his interest is in the 'fish's point of view' and which (of many) directions 'the fish swims in.' His archival research, he argues, differs from that of the professional scholar who seeks out evidence related to a specific question or theme. As a novelist, he is more interested in what we might term that 'thick' historical description which provides, so he puts it, 'a total picture of a place and its time, the landscape, the clothes, the languages, the states of mind and body', an understanding of 'what it was like to be present in that place, in that week, on that day.' At the same time, he has noted the lacunae in the scholarly histories, gaps which when he initially commenced work on his Ibis trilogy forced him to undertake the extensive primary research on which these novels rest. ${ }^{2}$

\footnotetext{
${ }^{1}$ The workshop, entitled "The Past in the Present: Histories in the Making", was held on November 17, 2007 at the National Museum of Singapore. The authors involved were Meira Chand, Chong Yen Chung and Kunal Basu.

${ }^{2}$ Buku Sarkar, "Writing is all about dealing with resistances: Amitav Ghosh", Live Mint, May 30, 2015, http://www.livemint.com/Leisure/D0gzVQF0bko8R5ZEJ26lxJ/Writing-is-all-about-dealing-with-resistancesAmitav-Ghosh.html. Last accessed August 19, 2016; Mahmood Kooria, "Between the Walls of Archives and the Horizons of the Imagination: An Interview with Amitav Ghosh", Itinerario, 36, no. 3 (2012): 7-18. The one branch of history Ghosh believes gives this 'total picture' is military history. On the scholarly merits of 'thick description' see Clifford Geertz's famous essay, "Thick Description: Toward an Interpretive Theory of Culture", in his The Interpretation of Cultures: Selected Essays (New York, 1973), 3-30.
} 
The dividing line is still there in these comments, and with good reason. Academic historians might, for their own personal knowledge and satisfaction, go digging for the same level of detail in which Ghosh excels. Rarely, however, does this kind of thick description make it into their final published manuscripts, except in the form of the anecdotes and vignettes which they utilize to introduce broader arguments and themes. Even scholars who adopt an overt micro-historical approach can never completely free themselves from the telos that validates such a perspective: their account of those wider causes, processes and consequences which define the passage of history. There is always some point at which the micro-historian pulls back to bring a wider context into view. While he or she might adopt the fish's point of view, it is with one eye fixed on explaining why the currents and crosscurrents flow the way they do, and on whether they have indeed determined the fish's movements in the ways other scholars claim that they have. ${ }^{3}$

Nonetheless, Amitav Ghosh is unlikely to ever escape scholarly judgements as to the merits of his historical fictions. He is, after all, a trained ethnographer and archival researcher with an Oxford DPhil in Social Anthropology (albeit one, he recalls, that was awarded to him on the basis of a thesis relatively free from footnotes and references). Such is the rigour of his research that one reviewer has noted of his World War Two novel The Glass Palace that it reads in places like a 'documentary on paper'. Another reviewer, the Modern European historian Jan Goldstein, has described her revelatory learning experience when reading the Ibis trilogy's first two instalments as she 'effortlessly' absorbed unfamiliar pasts. ${ }^{4}$ The thick description which Ghosh shares with his readers, in part to answer the questions which

\footnotetext{
${ }^{3}$ One of the finest exponents of such a micro-historical approach, as revealed in numerous monographs, is the renowned historian of China Jonathan Spence.

${ }^{4}$ Saloni Sharma, "Fiery End: Amitav Ghosh's Ibis Trilogy - the Story So Far", Quartz India, May 16, 2015, http://qz.com/411578/amitav-ghoshs-ibis-trilogy-the-story-so-far/. Last accessed August 19, 2016; Jan Goldstein, "Discovering Global History Through Historical Fiction: The Many Layers of Amitav Ghosh's Trilogy of Novels", Perspectives on History, November 2014, https://www.historians.org/publications-anddirectories/perspectives-on-history/november-2014/discovering-global-history-through-historical-fiction. Last accessed August 19, 2016.
} 
historians have failed to ask, cannot help but lead historians themselves towards new questions. To take one example, what exactly were the class, racial and sexual politics on display at the early nineteenth century male-only dances of Canton's foreign merchant community, which the author so brilliantly (and riotously) captures in River of Smoke, the second novel of his Ibis trilogy?

As a writer of history, Amitav Ghosh is also difficult to ignore because ever since the publication of his genre-bending In An Antique Land (1993) he has appeared ahead of the historiographical curve - not merely filling the gaps left by historians but leaping in front of them as torchbearer. His interest in exploring oceanic connections that in the past transcended the confines of modern nation states - across the Arabian Sea, the Bay of Bengal and the wider Indian Ocean - pre-empted the 'transnational turn' in contemporary history writing, which only really took off from the late-1990s. In the relatively young sub-discipline of Indian Ocean studies, he has rapidly attained a status as a pioneer literary deity, seated in the pantheon alongside his fellow Bengali voyager of a century earlier, Rabindranath Tagore. How well, then, under the scrutiny of those who might feel familiar with the historical scaffolding Ghosh erects - or, at least, familiar enough to be inured to the exoticism of the faces and places he depicts - does his rendering of the past hold up?

One of the marvels of the Ibis trilogy is the author's mastery of historical space. His thick description takes us aboard and then down into the innards of boats and ships. It carries us from the ghats of Bihar to the coolie depots of the Ganges Delta, then on to the boarding houses and colonial mansions of Calcutta, where, in a wonderful evocation of colonial modernity-cum-absurdity, we sit at a British merchant's dining table where the conversation is drowned out by a Thermantidote, an early attempt at air-conditioning. The author also deposits us, in the company of the protagonist of Sea of Poppies, the former-Raja Neel Rattan Halder, in the courtyards and cells of Alipore Jail, while in River of Smoke he transports us to 
the lanes, docks, pleasure boats, consulates and Thirteen Factories of Fanqui-town (foreigner's town) in late-1830s Canton. The outstanding descriptive set-piece in Flood of Fire, the final part of this trilogy, is his reconstruction of a mobile city: an East India Company army and its camp followers on the move. The skills of observation and reconstruction needed to so successfully recover these altogether very different spaces reveal Ghosh as a superb micro-historian.

The didactic value of this mastery of space is revealed through a scene that comes early in Sea of Poppies when Deeti, one of the novel's female protagonists, travels to the Ghazipur opium factory in search of her ailing, opium-addicted, husband. The natural recourse of historians when depicting the scale of early nineteenth century opium production in British India is to fall back on figures for the increasing tonnage of the drug that was exported to China. Amitav Ghosh's novelistic eye provides a more powerful human lens through which to appreciate the industrial scale of this enterprise - from the perspective of a distressed subaltern gazing up. Here, the author's imagination communicates to students something that the copies of period maps and lithographs which I have relied on in the classroom have never, by themselves, delivered: historical space as a lived environment in which people moved, talked, ate, loved, fought and died. ${ }^{5}$

But the Ibis trilogy gives students and scholars more than a memorable tour of historical sites across Indian Ocean world circa 1840. A further insight into the past not usually found in scholarly monographs is provided by the author's painstaking reconstruction of historical languages. The expert linguist and ethnographer in Ghosh cannot resist filling his trilogy with the babel of tongues formerly heard across the Indian Ocean. Sea of Poppies begins with an artillery-blast of sailors' insults, Hobson-Jobson, bastardized Hindi and

\footnotetext{
${ }^{55}$ Amitav Ghosh bases his vivid depiction of the Ghazipur opium factory on J. W. S. MacArthur's Notes on an Opium Factory (Calcutta, 1865).
} 
Lascari. At first, the author might be accused of showing off too much of the intense research that has enabled him to reproduce such a linguistic array, of letting his 'scaffolding' push through the novel's carefully woven fabric. However, when the initial lexicographical fireworks subside and the plot moves forward, such voices become less jarring, more an expected part of the world with which the reader is becoming familiar.

But if Ghosh merely did past sights and sounds he might still be accused of producing no more than that empty authenticity which several period dramas made for television and the cinema have excelled at. Thankfully, his historical interests range much further. Scholars have debated the economic and environmental impact of opium cultivation in Bengal, and its role in the famine of 1770 that is estimated to have killed ten million. ${ }^{6}$ In the arresting opening of Sea of Poppies, the author illuminates a further aspect of the drug's ecological legacy, one that though less contentious is just as revealing. In these pages, opium seeps into every corner of the land, even into Deeti's own household, to the extent that it becomes part of the essential habitus of life under British occupation. Here, as the author plays with the picturesque (poppy fields in bloom are dramatically pretty), he produces a metaphor for Western imperialism on a par with Rudyard Kipling's bridge in The Bridge Builders and Joseph Conrad's river steamboat in Heart of Darkness, both of which belong to a later colonial epoch. This is an imperialism, both colourful and menacing, which invades the Indian heartland. For a time, the likes of Deeti domesticate it and derive what use they can from it. Eventually, however, it corrupts and distorts, to the point where even the monkeys and butterflies are lulled into a doped-out reverie and the land eventually left parched and barren.

\footnotetext{
${ }^{6}$ See Sushil Chadhury, From Prosperity to Decline: Eighteenth Century Bengal (New Delhi, 1995); and more recently Vinita Damodaran, Anna Winterbottom and Alan Lester, The East India Company and the Natural World (New York, 2015).
} 
In other respects, Ghosh's broader historical concerns show him once again racing ahead of the academy. In Sea of Poppies, his depiction of Neel's fate at the hands of colonial 'justice', which the author based on a real forgery case of a decade earlier, appears to have pre-empted a spate of historical studies which have now examined the encounters of Indians and other imperial subjects with colonial law courts. ${ }^{7}$ Ghosh is also one of the few writers to examine the interwoven history of the imperial opium and indentured labour trades, whereas most scholars who specialize in these fields have tended to discuss them separately. His travels and studies seem to have given him a more innate sense of the connectedness of the Indian Ocean world than many historians possess. Only recently, one of the doyens of the field of Indian Ocean history summoned his fellow scholars to venture beyond their research into the networks which linked coasts and port-cities, to explore the rivers and river deltas which fed into this ocean, and the lives of inhabitants from these places who also found themselves drawn into the ocean's vast watery web. ${ }^{8}$ Ghosh, in his own way, has been exploring such places and connections since the appearance of Sea of Poppies, and before that through his 2004 novel The Hungry Tide.

On the other hand, when it comes to those he depicts as the victims of the two trades which dominate the plot of the Ibis trilogy, scholars and students might find him reliant on a historiography that is conservative if not dated. In Sea of Poppies, he presents indenture as the natural heir to slavery - indeed, as slavery by another name - whereas several historians now contest this easy succession. ${ }^{9}$ We do not learn that beginning in 1838 , in the same year

\footnotetext{
${ }^{7}$ See, inter alia, Elizabeth Kolsky, Colonial Justice in British India: White Violence and the Rule of Law (Cambridge, 2011); Shaunnagh Dorsett and John McLaren, Legal Histories of the British Empire: Laws, Engagements and Legacies (Abingdon, NY, 2014); Chandra Mallampalli, Race, Religion and Law in Colonial India: Trials of an Interracial Family (Cambridge, 2011).

${ }^{8}$ Sugata Bose, in his introductory remarks at the "Cosmopolitan Currents in the Indian Ocean: New Conceptual Models for Studying Cultural Integration and Change" conference, New York University Abu Dhabi, March 15, 2015.

9 For a recent summary of this historiographical shift see Sugata Bose, "Blackbirders Refitted? The Journeys of Capitalists and Labourers in the Indian Ocean, 1830s-1930s" in Jayati Bhattacharya and Coonoor Kripalani, eds., Indian and Chinese Immigrant Communities: Comparative Perspectives (London, 2015), 3-12.
} 
the novel is set, a highly self-conscious colonial state, under pressure from the anti-slavery lobby, established Commissions of Enquiry in India's three Presidencies to investigate abuses in the indenture system. Nor do we learn that as part of these investigations interviews were conducted with returned Indian migrants to Mauritius, or that a year later the emigration of labour overseas from India was banned and only reinstated in December 1842, following the introduction of new regulations intended to limit such abuses. ${ }^{10}$

Nor, in Amitav Ghosh's depictions of the effects of opium on its users, is there much consideration of the historian Frank Dikotter's startlingly revisionist arguments concerning the great 'opium myth'. In Sea of Poppies, all the author's habitual users conform in their various ways to late-Victorian depictions of the enslaved 'opium wreck' ${ }^{11}$ One of the most moving scenes in this novel comes when Neel nurses Ah Fatt, his Parsee-Chinese fellowconvict aboard the Ibis, through the especially violent agonies of an extreme opium withdrawal. The recent memoir of a twenty-first century opium addict indicates that such withdrawal symptoms were, for the twenty to thirty pipe a day smoker, hardly mythical. ${ }^{12}$ Nonetheless, the reality Frank Dikotter paints for nineteenth century China and beyond is that very few users were 'compulsive addicts' who 'lost control' or suffered from a 'failure of will'. Most were light and moderate users. Habitual users typically reached a plateau of between seven and fifteen pipes per day and were quite capable of reducing their dosage when forced to by the dynamics of supply and demand. Indeed, Frank Dikotter repeats in his study the claim that there is little hard evidence for the harmful physical effects of taking opium other than mild constipation. ${ }^{13}$ In a scene towards the end of Sea of Poppies, in which

\footnotetext{
${ }^{10}$ Marina Carter, Servants, Sirdars and Settlers: Indian in Mauritius, 1834-1874 (Oxford, 1995), 62-73

${ }^{11}$ As depicted by novelists such as Charles Dickens in Edwin Drood (1870) or Oscar Wilde in The Picture of Dorian Gray (1890). See Virginia Berridge and Griffith Edwards, Opium and the People: Opium Use in Nineteenth Century England (London, 1981), 197-200

${ }^{12}$ Steven Martin, Opium Fiend: A $21^{\text {st }}$ Century slave to a $19^{\text {th }}$ Century Addiction (New York, 2012)

${ }^{13}$ Frank Dikotter, Lars Laamann and Zhou Xun, Narcotic Culture: A History of Drugs in China (London, 2004); see also Frank Dikotter, “Patient Zero': China and the Myth of the 'Opium Plague'”, Inaugural Professorial
} 
Chillingworth, the captain of the Ibis, describes the normalcy of opium use in China to his second-mate Zachary Reid, the author appears to pay lip-service to these arguments. Yet coming from the mouth of the sad opium-using shell that Chillingworth has become, it is not clear why anyone should believe him.

No doubt, such a sometimes conservative historiography is partly a result of Amitav Ghosh's mission to write a novel of resistance which wakes his readers from their amnesia regarding the British Empire. In taking on this responsibility, we might argue, he artfully adopts the strategy which Edward Said once described as a 'voyage in' to 'write back' ${ }^{14}$ Reviewers have frequently noted that in the Ibis trilogy the author becomes a Victorian novelist. Whether consciously or subconsciously, Ghosh appropriates the genre of the Victorian novel to write against the greedy empire which produced it. Yet the problem with this devotion to unmasking unpalatable colonial pasts is that it affords little space for the portrayal of British imperialism and its oceanic trades as anything more complex than categorical evils. Indeed, at times the author appears to have voyaged so far into the rotten heart of the British Empire as to have swallowed elements of an Orientalizing discourse spread by its own anti-slavery and anti-opium lobbies, and thus tobe reiterating obvious Victorian racial and gender stereotypes.

This brings me to my main complaint about Amitav Ghosh's representation of the past, and to the main point where his historical imagination and my own part ways. In Sea of Poppies, the author frequently reveals an asymmetrical empathy with his characters. While his Indian characters, especially the gomusta (clerk) Baboo Nob Kissin and the disgraced Neel, spring to life with a compelling complexity, his principal European characters consist

Lecture at SOAS, October 2003, http://frankdikotter.com/publications/the-myth-of-opium.pdf. Last accessed August 19, 2016.

${ }^{14}$ Edward Said, Culture and imperialism (New York: Random House, 1994), 288-315. For Amitav Ghosh's views on the 'whitewashing' of this aspect of British imperialism, see his interview with the BBC, "Opium Financed British Rule in India”, BBC News, June 23, 2008. http://news.bbc.co.uk/1/hi/world/south_asia/7460682.stm. Last accessed 25 August, 2016. 
of crudely drawn naïfs (whom the author, on account of their non-Britishness, seems to let off the hook when it comes to colonial guilt) and British-born sadists. There is little room for what Zadie Smith, in praise of another author, has called those 'thin lines that separate evil from cruelty from unkindness from malevolent stupidity'. ${ }^{15}$ One of naïfs in Sea of Poppies is the wide-eyed American Zachary Reid, who at one point permits the lascars on the Ibis to fuss over him in a way which brought to mind Charlie, the only 'good boy' in Willie Wonka's Chocolate Factory, being led about by oompa loompas. Another is the innocent Paulette, who is described by her debt-ridden French father (in conversation with his creditor) as someone who has 'not known anything but Love, Equality, and Freedom'. The principle sadists are the Calcutta-based merchant Benjamin Burnham and the Ibis' first mate Mr. Crowle. Both men kick, swear, and humiliate their underlings, and then kick them again. Benjamin Burnham, if Paulette is to be believed, also has a penchant for nocturnal sadomasochistic rituals.

The issue here is not, as Amitav Ghosh in a 2012 interview seems to have assumed, that he ought to have written in some nicer Europeans, but that he should, when it comes to explaining what drives their violent actions, peer as deeply into their souls as he does those of his non-European characters. ${ }^{16}$ In terms of his understanding of the colonial psyche, his canvas in Sea of Poppies is not particularly wide nor nuanced, and so the evils of the imperialism he depicts remain only part-explained. For a fuller explanation, we rely on novelists such as Rudyard Kipling and Joseph Conrad who, for all their alleged and obvious racism, still enlighten us, at least from the colonizer's perspective, as to the psychology and the psychosis of the Western imperial project - no doubt because they themselves were at various times complicit in it.

\footnotetext{
${ }^{15}$ Zadie Smith, "Shades of Greene", The Guardian, September 18, 2004. https://www.theguardian.com/books/2004/sep/18/classics.grahamgreene. Last accessed August 25, 2016.

${ }^{16}$ Kooria, "Between the walls", 14.
} 
I make these criticisms with the first book in the Ibis trilogy mainly in mind. Few apply to River of Smoke which, though it might not have the 'magic' for some readers of the first instalment is, if judged purely on its reconstruction of history, an even better novel. Putting aside my quibbles over whether there were Tanka kitchen boats in late-1830s Singapore, and why everyone in Canton seems to have forgotten about William Napier and the Pearl River debacle of 1834, this book proves that Ghosh's skills with thick description extend not merely to sounds and spaces, but to the majority of his characters - and especially, to his European characters. Several of the Europeans merchants he portrays in Canton are, of course, famous and infamous historical personalities, and he draws them with a far greater subtlety - a result, no doubt, of meticulous research using primary sources that revealed to the author their actual thoughts and voices.

Yet perhaps Amitav Ghosh's finest creation in River of Smoke, if not in his entire trilogy, is the Parsee opium trader Bahram Modi. Through Bahram, he conjures into life the whole world of what Sugata Bose has termed 'intermediary capital' - and once again, through Barham's tragic end, he reminds us of its human cost. ${ }^{17}$ In the process, and again revealing a brilliant eye for detail, he moves us on from what has been a rather simpler story of masters, servants and slaves to a more complex examination of the collaboration and the complicity on which the edifice of an opium-fuelled British Empire rested. In Flood of Fire, depictions of the more complex relationships generated by British imperialism in the Indian Ocean - across caste, gender, religion and race - also abound, and the author examines them with a similar intelligence and sensitivity.

I hesitate to say this, because it would likely have been impractical, but I almost wish Ghosh had completed his historical research for the Ibis trilogy before he embarked on

\footnotetext{
${ }^{17}$ Sugata Bose, A Hundred Horizons: The Indian Ocean in the Age of Global Empire (Cambridge, Mass., 2006), 72-121.
} 
writing its opening instalment. With his depiction of the tragic Bahram Modi, and (in Flood of Fire) his equally impressive portrait of the Indian sepoy Kesri, the brother of Deeti and friend of the English officer Captain Mee, it becomes clear that as he has delved deeper and deeper into the vast history he draws upon, he has emerged as an even better (for want of a better word) historian. 